\title{
PENGEMBANGAN KETRAMPILAN WIRAUSAHA SOSIAL BAGI SISWA SMP AL JANNAH PONDOK RANGGON, JAKARTA TIMUR
}

\author{
Halim Putera Siswanto ${ }^{1}$ dan Hetty Karunia Tunjungsari ${ }^{2}$ \\ ${ }^{1}$ Jurusan Manajemen, Universitas Tarumanagara, Jakarta \\ Email: halims@fe.untar.ac.id \\ ${ }^{2}$ Jurusan Manajemen, Universitas Tarumanagara, Jakarta \\ Email: hetty@fe.untar.ac.id
}

\begin{abstract}
The community engagement team of Universitas Tarumanagara so far has been routinely involved in the entrepreneurship construction program in the 'Al Jannah' Junior High School. Several workshop activities that have been conducted by this team are expected to be continually provided to the students in this school. During the organization of these community engagement activities, besides providing the material regarding entrepreneurship, the team also invited some speakers from various fields of entrepreneurship. In the entrepreneurship construction program, the school also attempted to equip the students with various entrepreneurial skills, starting from the delivery of materials about how to seek business opportunities, recognizing the self-potentials, to those about direct knowledge transfer from the real entrepreneurship. During this pandemic, the school attempt to seek entrepreneurs who are willing to be the speakers to share their entrepreneurial experiences to the students, either through online or offline ways. On this occasion, the team of Universitas Tarumanagara was invited to conduct an activity regarding the social entrepreneurship. Besides delivering the material about social entrepreneurship, this kind of activity also involved some speakers experiencing the business in this field. In order to accommodate this necessity, the team invited Ranny Kreasi that produces handicrafts from used-newspaper materials as the speaker.
\end{abstract}

Keywords: social entrepreneurship, SME, creative product, recycled material

\begin{abstract}
ABSTRAK
Tim PKM Universitas Tarumanagara selama ini secara rutin turut terlibat dalam program pembinaan Kewirausahaan di SMP Al Jannah. Beberapa kegiatan workshop yang pernah dilakukan oleh tim PKM Universitas Tarumanagara secara kontinyu diharapkan dapat terus diselenggarakan pada siswa di sekolah ini. Dalam penyelenggaraan kegiatan PKM, tim PKM Universitas Tarumanagara selain memberikan materi seputar Kewirausahaan juga mengundang sejumlah narasumber dari wirausaha di berbagai bidang. Dalam program pembinaan Kewirausahaan ini, pihak sekolah berupaya membekali siswa dengan berbagai ketrampilan berwirausaha, mulai dari penyampaian materi seputar mencari peluang usaha, mengenali potensi diri, hingga materimateri yang sifatnya transfer knowledge dari wirausaha langsung. Saat pandemi, sekolah mencoba mencari wirausaha yang bersedia menjadi narasumber untuk menularkan pengalaman berwirausaha mereka bagi para siswa baik secara daring maupun luring. Pada kesempatan kali ini, tim PKM Universitas Tarumanagara diminta untuk memberikan kegiatan dengan materi utama berupa Kewirausahaan Sosial. Selain menyampaikan materi mengenai Kewirausahaan Sosial, diharapkan kegiatan PKM juga melibatkan narasumber wirausaha yang menggeluti bisnis di bidang ini. Untuk mengakomodasi kebutuhan ini, tim PKM mengundang narasumber Ranny Kreasi yang memproduksi kerajinan tangan dari bahan baku koran bekas.
\end{abstract}

Kata kunci: kewirausahaan sosial, UKM, produk kreatif, bahan daur ulang

\section{PENDAHULUAN}

\section{Analisis Situasi}

Membangun social enterprise atau kewirausahaan sosial kini kian menjadi tren di tengah masyarakat yang ada di seluruh dunia, termasuk di Indonesia. Para pendiri dan pekerja wirausaha sosial ini memiliki peran yang sangat substansial bagi perbaikan berbagai isu sosial yang sedang dihadapi di era sekarang ini. Dengan memanfaatkan teknologi dan inovasi terbaru, para wirausahawan inspiratif ini selalu berusaha untuk menciptakan dampak yang akan meningkatkan kualitas kehidupan di sekitar mereka. Di dunia kewirausahaan sosial, mengejar uang bukanlah motivasi yang utama. Menjadi agen perubahan untuk dunia adalah hal yang terpenting bagi mereka. 
Salah satu faktor pendorong munculnya Kewirausahaan Sosial adalah adanya inovasi. Sejumlah penelitian membuktikan bahwa dari berbagai bentuk inovasi yang ada di berbagai negara, terdapat empat faktor utama yang menjadikan sebuah perusahaan lebih inovatif dibandingkan dengan perusahaan lainnya. Empat faktor tersebut adalah tenaga kerja ahli, sumber daya modal, dukungan pemerintah, serta budaya (Bartholomew, 1997; Demirgüç-Kunt \& Levine 2001; Furman et al., 2002; Nelson, 1993).

Inovasi dibutuhkan untuk tetap dapat memenangkan persaingan di pasar. Dalam konteks berbisnis, wirausaha-wirausaha saat ini dihadapkan pada berbagai tantangan perubahan, baik dari segi perkembangan produk, perubahan selera konsumen, hingga peraturan pemerintah yang dapat merubah kegiatan berbisnis. Kebutuhan untuk dapat menciptakan produk yang lebih baik dalam waktu yang lebih singkat dan biaya yang lebih efisien hampir menjadi kendala bagi seluruh wirausaha di industri mana pun. Oleh karena itu, tantangan utama yang dihadapi oleh wirausaha saat ini adalah menciptakan inovasi-inovasi baru yang berkelanjutan dan tepat waktu untuk dapat mencapai keberlangsungan usaha dalam jangka panjang (Christensen, 1997).

Perkembangan jaman dan pesatnya perubahan teknologi memposisikan perusahaan untuk terusmenerus melakukan peningkatan kualitas usaha agar dapat bertahan dan berkembang lebih besar. Permasalahan yang muncul dari perkembangan kebutuhan dan keinginan pelanggan serta kondisi persaingan usaha yang makin ketat dan penuh ketidakpastian membutuhkan berbagai pemikiran kreatif dan tindakan-tindakan inovatif sebagai solusinya. Jika sebuah perusahaan tidak mampu dan tidak mau beradaptasi dengan perkembangan zaman, maka lambat laun perusahaan tersebut akan tersingkir oleh persaingan bisnis. Oleh sebab itu maka kreativitas dan inovasi merupakan sebuah pemikiran dan tindakan yang wajib dimiliki oleh seorang wirausaha dan dilakukan secara berkesinambungan tanpa henti sebagai upaya mempertahankan kelangsungan usahanya.

Sejak tahun 2020 Indonesia mengalami pandemi COVID-19 yang memaksa dunia pendidikan beralih ke aktivitas online. Hal ini tentu memerlukan adaptasi baik bagi sekolah selaku penyelenggara pendidikan maupun siswa selaku sasaran pendidikan. aktivitas belajar mengajar dijalankan secara daring dengan memanfaatkan berbagai sumber daya dan mengadaptasi metode sesuai kurikulum pembelajaran. Di beberapa kesempatan, saat kebijakan aktivitas luring dapat dijalankan sesuai dengan prokes yang ketat, sekolah juga memanfaatkan kesempatan ini untuk menyelenggarakan pembelajaran di dalam sekolah secara terbatas.

SMP Al Jannah Pondok Ranggon, Cibubur, Jakarta Timur, adalah salah satu sekolah yang mengutamakan ketuntasan belajar siswa melalui metode hybrid di tengah situasi pandemi COVID19. Pihak sekolah menyusun jadwal belajar tatap muka terbatas di lingkungan sekolah dengan penerapan prosedur kesehatan yang ketat, seperti misalnya pembelajaran di ruang terbuka, jumlah siswa yang terbatas, penggunaan masker dan face shield, pengaturan jarak, penyediaan hand sanitizer dan tempat cuci tangan, dan lain-lain. Pimpinan sekolah memberlakukan pertemuan tatap muka di sekolah untuk siswa-siswa yang telah mendapatkan ijin dari orang tua.

Kegiatan yang dilakukan siswa saat belajar tatap muka di sekolah, selain untuk menyelesaikan materi ajar, juga meliputi kegiatan pembinaan kewirausahaan. Sekolah telah secara rutin menyelenggarakan berbagai kegiatan Kewirausahaan, namun terjadi sedikit kendala saat pandemi COVID-19. Pada kegiatan terdahulu, selain siswa mengikuti pembinaan Kewirausahaan, siswa juga diberi tugas untuk mengadakan pameran kewirausahaan secara berkelompok. Karena pandemi, kegiatan pameran ini kemudian ditiadakan. Namun pembinaan kewirausahaan tetap dijalankan oleh sekolah tanpa penyelenggaraan pameran. 


\section{Permasalahan Mitra}

Sekolah Al Jannah memiliki visi untuk menjadi sekolah yang mengajarkan sains, agama, dan cinta kepada alam bagi para siswanya. Selain itu, sekolah ini juga memiliki visi khusus untuk mengembangkan jiwa wirausaha bagi setiap siswa. Oleh sebab itu, pihak sekolah, dalam hal ini adalah SMP Al Jannah, secara rutin mengadakan kegiatan-kegiatan yang dapat mengimplementasikan pemahaman siswa akan sains, agama, cinta alam dan kewirausahaan. Sekolah selama ini secara rutin menyelenggarakan program-program kewirausahaan bagi siswa, termasuk melibatkan siswa dalam berbagai kegiatan bazaar Kewirausahaan yang menampilkan produk-produk karya siswa. Salah satu hal yang ingin ditanamkan sekolah kepada para siswa adalah pentingnya menciptakan lapangan pekerjaan sebagai bentuk kontribusi wirausaha dalam menyelesaikan permasalahan sosial di masyarakat. Konsep ini dikenal juga sebagai Kewirausahaan Sosial.

Saat pandemi, sekolah mengalami kendala dalam proses pembelajaran program kewirausahaan secara praktik. Untuk mengatasi permasalahan ini, sekolah mencoba mencari wirausaha yang bersedia menjadi narasumber untuk menularkan pengalaman berwirausaha mereka bagi para siswa baik secara daring maupun luring. Pada kesempatan kali ini, tim PKM Universitas Tarumanagara diminta untuk memberikan kegiatan dengan materi utama berupa Kewirausahaan Sosial. Selain menyampaikan materi mengenai Kewirausahaan Sosial, diharapkan kegiatan PKM juga melibatkan narasumber wirausaha yang menggeluti bisnis di bidang ini. Untuk mengakomodasi kebutuhan ini, tim PKM mengundang narasumber Ranny Kreasi yang memproduksi kerajinan tangan dari bahan baku koran bekas.

Kegiatan PKM ini diharapkan mampu memberikan solusi bagi SMP Al Jannah Islamic Nature and Science School dalam upayanya mengembangkan program kewirausahaan bagi siswa, terutama dalam menumbuhkan semangat Kewirausahaan Sosial sesuai dengan visi dan misi sekolah. Kegiatan ini direncanakan akan terdiri dari dua metode, yakni sosialisasi mengenai Kewirausahaan Sosial serta pembekalan ketrampilan berwirausaha dalam bentuk workshop di bidang Kewirausahaan Sosial. Target yang ingin dicapai dalam kegiatan PKM pada tahap ini adalah terbukanya wawasan siswa mengenai Kewirausahaan Sosial serta terbentuknya ketrampilan untuk menciptakan produk yang memiliki kontribusi sosial.

\section{Solusi Permasalahan}

Solusi yang ditawarkan untuk menyelesaikan permasalahan mitra dalam bidang manajemen meliputi hal-hal berikut ini:

a. Untuk menyelesaikan masalah mitra dalam bidang manajemen, dalam hal ini adalah mendukung proses pembelajaran kewirausahaan bagi siswa di SMP Al Jannah melalui pengenalan konsep Wirausaha Sosial.

b. Selain memberikan pengenalan konsep Wirausaha Sosial, PKM ini juga memfasilitasi transfer ketrampilan berwirausaha dalam bentuk penyelenggaraan workshop kerajinan dari bahan daur ulang kertas koran.

c. Target yang ingin dicapai dari kegiatan ini adalah terbentuknya pemahaman siswa akan pentingnya wirausaha sosial serta siswa mampu menguasai ketrampilan berwirausaha melalui workshop kerajinan bahan daur ulang kertas koran. Untuk mencapai target ini, tim melibatkan UKM Ranny Kreasi yang memproduksi kerajinan berbahan baku daur ulang dari kertas koran.

\section{METODE PELAKSANAAN PKM}

Metode pelaksanaan yang akan digunakan dalam kegiatan ini adalah sebagai berikut:

1. Pengumpulan data dan penyusunan proposal. Dalam menyusun proposal kegiatan PKM, tim melakukan wawancara dengan pihak sekolah SMP Al Jannah untuk mengidentifikasi masalah 
mitra. Setelah diketahui permasalahan yang dihadapi mitra, tim PKM melakukan studi literatur untuk mencari solusi yang tepat bagi permasalahan mitra.

2. Pelaksanaan. Pelaksanaan kegiatan PKM adalah dengan melakukan sosialisasi dan workshop secara tatap muka di sekolah dengan penerapan prosedur kesehatan.

3. Penyusunan dan penyerahan laporan. Kegiatan ini dilaksanakan untuk siswa SMP Al Jannah. Tujuan kegiatan PKM adalah untuk memberikan pemahaman pada siswa mengenai wirausaha sosial serta memberikan ketrampilan mengenai pembuatan produk kerajinan berbahan baku daur ulang kertas koran. Setelah kegiatan ini dilaksanakan maka tim PKM menyusun laporan dan menyusun publikasi terkait dengan kegiatan ini. Hasil dari kegiatan ini nantinya akan dijadikan dasar untuk menyusun rencana kegiatan lanjutan.

\section{HASIL DAN PEMBAHASAN}

Kegiatan diselenggarakan pada hari Rabu, 23 Juni 2021, pukul 08.00-11.00 WIB. Acara dibuka oleh pihak sekolah dan dilanjutkan dengan pemaparan oleh Ketua Tim PKM mengenai pentingnya Kewirausahaan Sosial. Materi yang disampaikan meliputi definisi Kewirausahaan Sosial, peran penting Kewirausahaan Sosial bagi kesejahteraan masyarakat, serta berbagai contoh mengenai bentuk Kewirausahaan Sosial yang dapat ditemukan di sekitar kita.

Sesi berikutnya diisi oleh narasumber UKM, Ibu Haerani sebagai pemilik UKM Ranny Kreasi yang memiliki usaha di bidang kerajinan dari bahan koran bekas. Ibu Haerani memandu workshop bersama ibu Muthia selaku guru pendamping kelas 7. Workshop ini diikuti oleh para siswa secara daring. Para siswa menyiapkan koran bekas di rumah masing-masing dan kemudian membuat produk sesuai dengan kreativitas mereka dengan mengikuti instruksi dari Ibu Haerani.

Gambar-gambar berikut ini menampilkan situasi kegiatan PKM yang berjalan secara hybrid. Tim PKM yang mengikuti kegiatan di sekolah adalah Ibu Hetty Karunia Tunjungsari, sementara Bapak Halim Putera Siswanto mengikuti kegiatan secara online via Zoom Meeting.

\section{Gambar 1}

Tim PKM Bersama Guru dan Narasumber di Sekolah

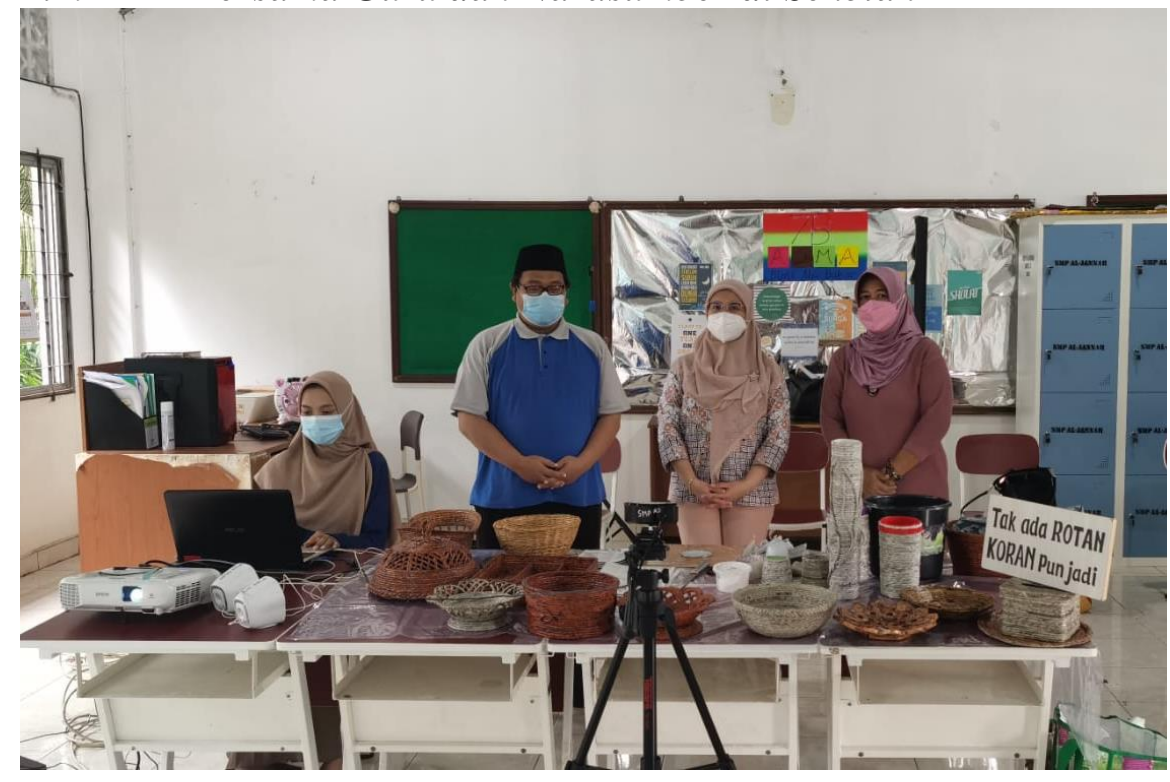

Situasi kegiatan pada Gambar 1 menampilkan tim PKM bersama guru dan narasumber yang menyelenggarakan kegiatan di sekolah. Pada gambar tersebut dapat dilihat bahwa guru sedang 
memandu siswa untuk mengikuti kegiatan melalui Zoom Meeting dan memperkenalkan tim PKM serta narasumber workshop pada para siswa. Gambar 2 menampilkan bahan-bahan yang digunakan untuk membuat kerajinan dari koran bekas. Bahan-bahan ini terdiri dari koran bekas, lem fox, cetakan, kuas, vernis, serta cat air.

\section{Gambar 2}

Bahan Workshop dan Contoh Produk Kerajinan Kertas Koran

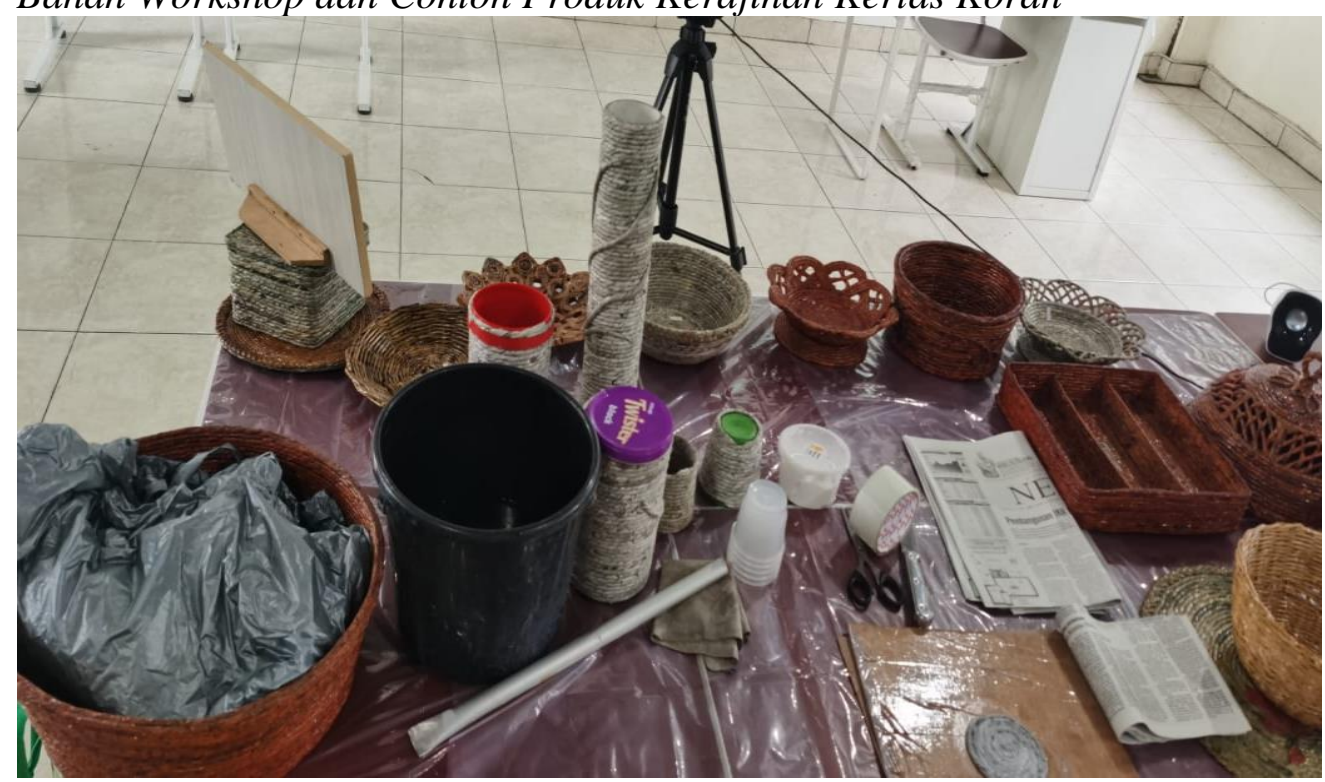

\section{Gambar 3}

Ibu Haerani Menjelaskan Contoh-Contoh Produk Kerajinan

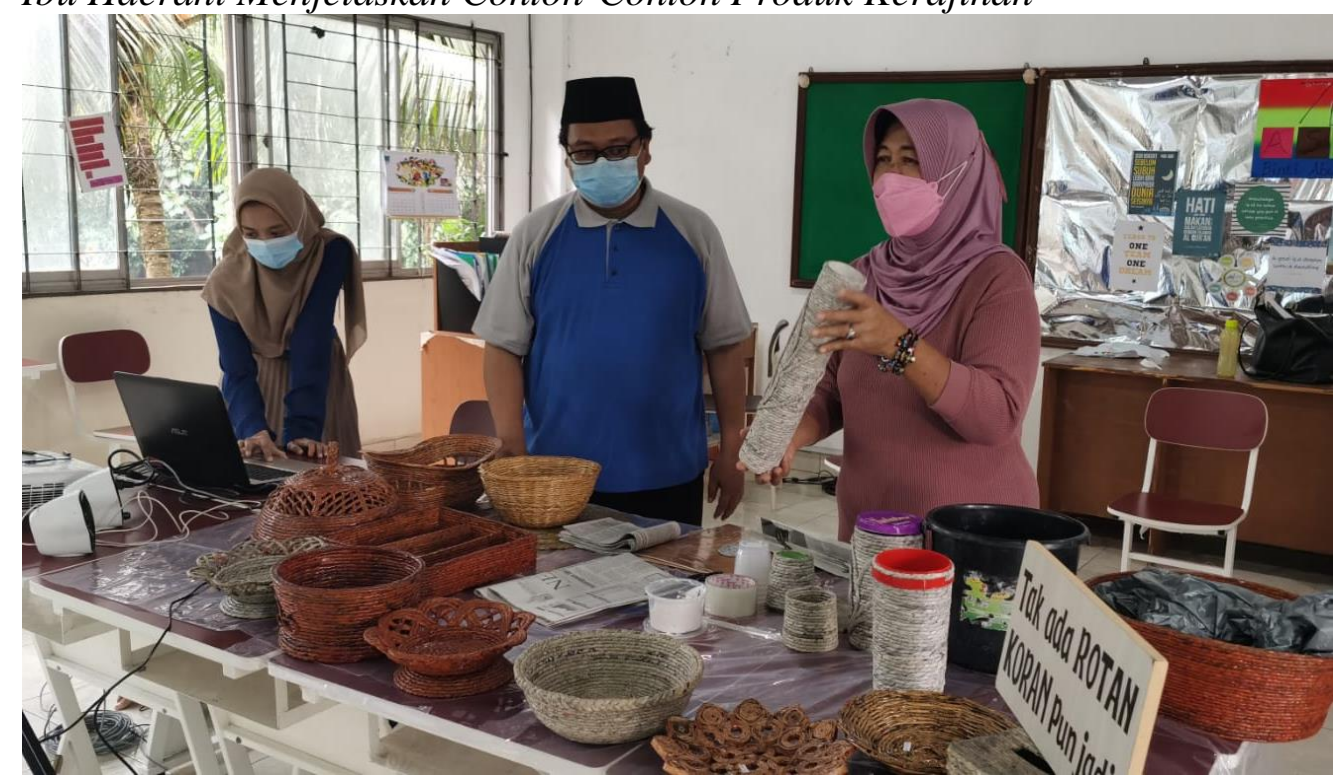

Pada Gambar 3 dapat dilihat berbagai contoh produk kerajinan yang dihasilkan dari kertas koran. Jika dilihat sepintas, produk kerajinan ini hampir menyerupai kerajinan rotan. Oleh sebab itu, Ibu Haerani juga sering mempromosikan produknya dengan slogan "Tidak Ada Rotan, Koran pun Jadi". Peserta mengikuti kegiatan dengan cukup antusias walaupun kegiatan diikuti secara online. Peserta kegiatan adalah para siswa kelas 7 yang terdiri dari 68 siswa. Foto para siswa yang mengikuti kegiatan melaui Zoom Meeting dapat dilihat pada Gambar 4 dan 5. 
Proses membuat kerajinan koran dimulai dengan memotong korang seukuran lebar $1 \mathrm{~cm}$. Setelah koran dipotong-potong, selanjutnya direndam dalam air kemudian ditiriskan airnya dengan cara diangin-anginkan. Tujuan merendam dalam air adalah agar nanti koran mudah dipilin. Potongan koran yang telah melalui proses perendaman dan penirisan, selanjutnya potongan koran dipilin satu persatu menjadi seperti tambang. Hasilnya menjadi tambang dari koran yang kemudian dapat dibentuk sesuai keinginan.

Cetakan yang dapat digunakan untuk membuat produk dapat dipilih sesuai keinginan dan menggunakan produk-produk yang ada di rumah. Sebagai contoh, kita bisa membuat keranjang buah dengan menggunakan baskom plastik, membuat celengan dengan menggunakan kaleng bekas, atau membuat alas piring dengan menggunakan alas piring yang ada. Tali koran dililitkan ke cetakan sesuai bentuk, kemudian diolesi dengan lem. Selanjutnya, produk yang sudah jadi dapat dikeringkan di bawah sinar matahari atau dapat didiamkan di ruang terbuka hingga kering. Setelah kering, cetakan dapat diangkat dan kemudian produk dapat dihias menggunakan cat air atau cukup dioles vernis saja.

\section{Gambar 4}

Proses Memilin Kertas Koran yang Ditampilkan Melalui Zoom Meeting

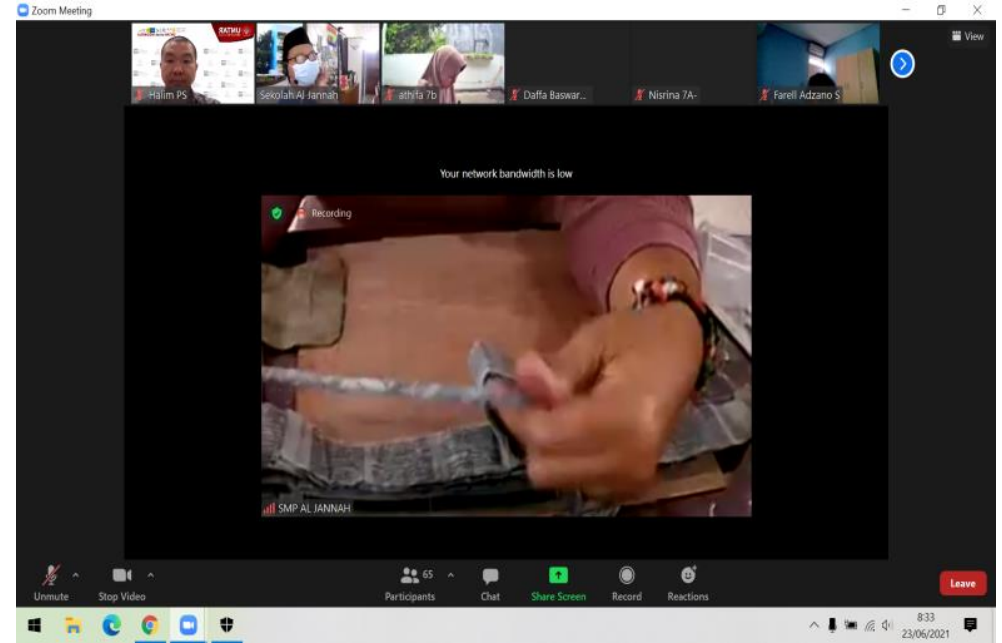

\section{Gambar 5}

Situasi Peserta Workshop Online

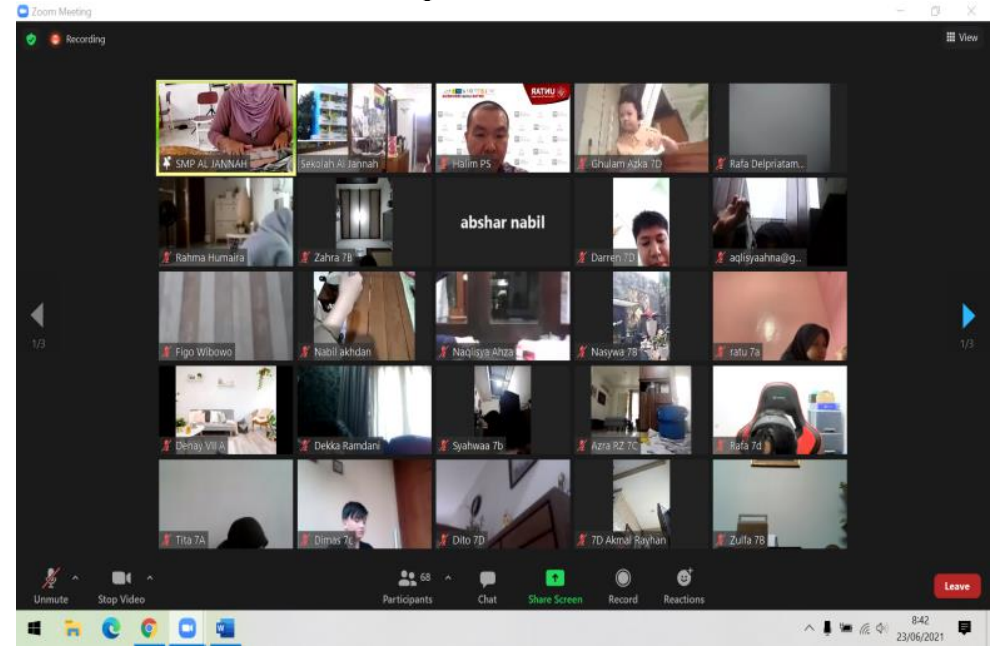


Kegiatan PKM yang bentuk workshop mengenai kerajinan tangan dengan menggunakan bahan bekas juga dilakukan oleh Husadha et al. (2019). Dalam kegiatan tersebut, Husadha et al. (2019) mengajak anak-anak yatim di Rumah Yatim Bekasi untuk membuat kerajinan tangan dari kertas dan plastik. Dalam hal ini, peserta diajak memanfaatkan barang bekas yang ada di sekitar mereka dan mengolahnya menjadi produk yang bernilai. Hal ini juga dilakukan melalui kegiatan PKM yang telah diselenggarakan oleh tim PKM Untar.

Untuk dapat menumbuhkan jiwa kewirausahaan sosial, masyarakat dapat diberikan penyuluhan mengenai pentingnya Kewirausahaan Sosial seperti yang dilakukan oleh tim PKM Untar saat ini di SMP Al Jannah. Kegiatan PKM serupa juga dilakukan oleh Yusriadi et al. (2020) pada ibu-ibu PKK di Kecamatan Cina Kabupaten Bone. Dengan memperkenalkan Kewirausahaan Sosial secara luas, diharapkan masyarakat dapat semakin tergugah untuk menciptakan kegiatan-kegiatan berwirausaha yang dapat berkontribusi pada pemecahan berbagai masalah sosial di masyarakat. Secara praktik, pelaku Kewirausahaan Sosial dapat menciptakan lapangan pekerjaan sehingga pada tingkat ekonomi makro dapat menurunkan tingkat pengangguran di masyarakat serta meningkatkan pendapatan per kapita (Saragih, 2017). Kewirausahaan Sosial pada akhirnya dapat berkontribusi dalam upaya pengentasan kemiskinan di masyarakat (Firdaus, 2014).

\section{KESIMPULAN}

Kegiatan PKM ini ditujukan untuk memperkenalkan Kewirausahaan Sosial bagi para siswa SMP Al Jannah, Pondok Ranggon, Cibubur, Jakarta Timur. Kegiatan dilakukan dengan memberikan penyuluhan mengenai Kewirausahaan Sosial serta menyelenggarakan workshop mengenai ketrampilan membuat produk kerajinan dari bahan koran bekas yang dipandu oleh narasumber UKM Ranny Kreasi. Secara keseluruhan, kegiatan PKM ini berjalan dengan baik dan mendapat respon yang positif, baik dari peserta maupun dari pihak sekolah. Di masa mendatang, kegiatankegiatan serupa dapat diselenggarakan di berbagai kalangan masyarakat untuk dapat lebih mengenalkan Kewirausahaan Sosial secara luas.

\section{Ucapan Terima Kasih (Acknowledgement)}

Pada kesempatan ini tim PKM menyampaikan ucapan terima kasih pada LPPM Universitas Tarumanagara yang telah memberikan pendanaan untuk kegiatan PKM ini melalui skema hibah PKM internal. Kami juga menyampaikan ucapan terima kasih pada Ibu Endiyah Widayatun, M.M. selaku Kepala SMP Al Jannah Islamic Science and Nature School dan Ibu Haerani selaku narasumber dan pemilik UKM Ranny Kreasi.

\section{REFERENSI}

Bartholomew, K. (1997). Adult attachment processes: Individual and couple perspectives. Psychology and Psychotherapy, 70(3), 249-263.

Demirguc-Kunt, A. \& Levine, R. (2001). Financial Structures and Economic Growth: A CrossCountry Comparison of Banks, Markets and Development. MIT Press.

Firdaus, N. (2014). Pengentasan Kemiskinan melalui Pendekatan Kewirausahaan Sosial. Jurnal Ekonomi Pembangaunan, 22(1), 55-67.

Furman, J.L., Porter, M.E., and Stern, S. (2002). The Determinants of National Innovative Capacity. Research Policy, 31(6), 899-933.

Husadha, C., Meutia, K.I., Narpati, B. (2019). Pelatihan Kewirausahaan dan Kerajinan Tangan Di Rumah Yatim Bekasi. Jurnal Abdimas (Pengabdian kepada Masyarakat) UBJ, 2(2), 141153.

Nelson K. (1993). The Psychological and Social Origins of Autobiographical Memory. Psychological Science, 4(1), 7-14. doi:10.1111/j.1467-9280.1993.tb00548.x. 
Saragih, R. (2017). Membangun Usaha Kreatif, Inovatif, dan Bermanfaat melalui Penerapan Kewirausahaan Sosial. Jurnal Kewiraushaan, 3(2), 26-34.

Yusriadi, Y., Tahir, S. Z., Awaluddin, M., \& Misnawati, M. (2020). Pengentasan Kemiskinan melalui Socialpreneur. Wikrama Parahita: Jurnal Pengabdian Masyarakat, 4(2), 115-120. https://doi.org/10.30656/jpmwp.v4i2.2529 